\title{
Laser-Induced Breakdown Spectroscopy (LIBS) for Monitoring the Formation of Hydroxyapatite Porous Layers
}

\author{
Daniel Sola ${ }^{1, *}$, Daniel Paulés ${ }^{2}$, Lorena Grima ${ }^{3}$ and Jesús Anzano ${ }^{2}$ \\ 1 Laboratorio de Óptica, Centro de Investigación en Óptica y Nanofísica, Universidad de Murcia, \\ Campus Espinardo, 30.100 Murcia, Spain \\ 2 Laboratorio Láser, Dpto. Química Analítica, Universidad de Zaragoza, 50.009 Zaragoza, Spain; \\ danipaules25@gmail.com (D.P.); janzano@unizar.es (J.A.) \\ 3 Instituto de Ciencia de Materiales de Aragón, Dpto. Ciencia y Tecnología de Materiales y Fluidos, \\ Universidad de Zaragoza-CSIC, 50.018 Zaragoza, Spain; lgrima@unizar.es \\ * Correspondence: daniel.sola@um.es; Tel.: +34-868-884-508
}

Received: 15 November 2017; Accepted: 4 December 2017; Published: 6 December 2017

\begin{abstract}
Laser-induced breakdown spectroscopy (LIBS) is applied to characterize the formation of porous hydroxyapatite layers on the surface of $0.8 \mathrm{CaSiO}_{3}-0.2 \mathrm{Ca}_{3}\left(\mathrm{PO}_{4}\right)_{2}$ biocompatible eutectic glass immersed in simulated body fluid (SBF). Compositional and structural characterization analyses were also conducted by field emission scanning electron microscopy (FESEM), energy dispersive X-ray spectroscopy (EDX), and micro-Raman spectroscopy.
\end{abstract}

Keywords: laser-induced breakdown spectroscopy; eutectic glass; bioactive materials

\section{Introduction}

A new era for tissue engineering has emerged since the discovery of a bioactive glass by Hench et al. in 1970 [1]. In particular, silicon and silicon calcium phosphate materials have attracted scientist's attention for being used as scaffolds in orthopaedic, oral, and maxillofacial applications. These materials, during exposure to simulated body fluid (SBF), develop a hydroxyapatite (HA) layer on their surface [2]. This reaction starts on the surface and usually leads to harmful shear-stress [3]. To enhance the ingrowth and the bioactivity of the ceramic implant, a suitable interconnected porous structure network is commonly utilized, which also provides a higher bioactivity rate and improves both the anchoring of the prosthesis and the blood and nutrition supply for the ingrowth of the new bone [4-7].

A novel path to accomplish in situ interconnected pore networks has been developed departing from dense bioactive and resorbable eutectic glass-ceramic and glasses of the $\mathrm{CaO}-\mathrm{SiO}_{2}-\mathrm{P}_{2} \mathrm{O}_{5}$ and $\mathrm{CaO}-\mathrm{SiO}_{2}-\mathrm{P}_{2} \mathrm{O}_{5}-\mathrm{MgO}$ systems [8-10]. Directionally-solidified eutectic ceramic (DSEC) oxides are composite ceramics obtained departing from a melt. Solidification conditions allow controlling the resulting microstructure and, hence, the material properties, making them suitable for structural and functional applications [11-16]. In particular, the $\mathrm{CaSiO}_{3} / \mathrm{Ca}_{3}\left(\mathrm{PO}_{4}\right)_{2}$ eutectic composite shows remarkable optical properties. Its spectroscopic properties can be used as optical probes for biomedical applications [17-19]. Additionally, optical waveguides inscribed in this eutectic glass by means of the ultrafast laser inscription technique suggested a great potential for being used as integrated photonic devices, optical amplifiers, and laser sources [20,21]. Furthermore, this eutectic binary composite presents bioactive characteristics since wollastonite (W), $\mathrm{CaSiO}_{3}$, is bioactive with osteostimulative properties and tricalcium phosphate (TCP), $\mathrm{Ca}_{3}\left(\mathrm{PO}_{4}\right)_{2}$, is osteoconductive and 
bioactive (resorbable) $[22,23]$. Both in vitro and in vivo biocompatibility, and bioactivity of this eutectic composite, have been widely studied for the last two decades [8-10,22-27].

In this work, we report on the characterization of the hydroxyapatite porous layer developed on the surface of the W-TCP eutectic glass after being immersed in SBF by using the laser-induced breakdown spectroscopy (LIBS) technique that is based on the generation of micro-plasma and emission spectroscopy measurements. In this technique, a high-energetic laser pulse, used as an atomization and excitation source, is directly focused on the sample surface and the formed plasma is analysed to obtain the multi-elemental composition of samples. LIBS is a single step, fast, robust, and stable technique with high spatial resolution, which can be carried out under atmospheric conditions [28]. In addition, sample preparation is not required, thus, providing a wide range of advantages when compared to other analytical techniques [29-33]. It is well-known that the W-TCP eutectic composite is capable of rearranging its morphology when it is soaked in human parotid saliva (HPS) or SBF so that the $\mathrm{W}$ phase is dissolved and the TCP phase undergoes a pseudomorphic transformation into HA $[8,9,23,24]$. Hence, the dense W-TCP ceramic is turned into a HA porous layer. The principal aim of this work is to assess the Si content of the sample surface by LIBS analysis to confirm the absence of this element in the layer generated after the sample being soaked into SBF and to conduct compositional and structural characterization analyses by field emission scanning electron microscopy (FESEM), energy dispersive X-ray spectroscopy (EDX) and micro-Raman spectroscopy to corroborate the presence of HA.

\section{Experimental}

\subsection{Sample Fabrication}

Eutectic glass samples were manufactured by means of the laser floating zone (LFZ) technique. This technique has been described in detail elsewhere [11,34,35]. For this purpose, tricalcium phosphate and wollastonite powders were mixed in the eutectic $20 \% \mathrm{Ca}_{3}\left(\mathrm{PO}_{4}\right)_{2}, 80 \% \mathrm{CaSiO}_{3} \mathrm{~mol} \%$ composition. The resulting powders were isostatically pressed at $200 \mathrm{MPa}$ for $2 \mathrm{~min}$ to obtain ceramic rods which were sintered at $1200{ }^{\circ} \mathrm{C}$ for $10 \mathrm{~h}$. Samples were grown in air and annealed at $650{ }^{\circ} \mathrm{C}$ for $5 \mathrm{~h}$ to relieve inner stresses. The development of the HA layer on the surface of the glass samples was carried out by soaking, for a one-month period, a glass sample in SBF, prepared according to the standard process [36]. The sample was kept at the human body temperature of $37^{\circ} \mathrm{C}$ by means of a Memmer Beschickung-loading-model 100-800 stove (Memmert GmbH, Schwabach, Germany).

\subsection{Characterization Techniques}

LIBS characterization was carried out by means of a Q-switched Nd:YAG laser (Brilliant Quantel, model Ultra CFR, Les Ulis Cedex, France) with emission at 1064 nm, emitting 7.7 ns laser pulses with $50 \mathrm{~mJ}$ maximum pulse energy. Plasma emission was collected by using a bifurcated optical fiber (QBIF600-UV-VIS, $600 \mu \mathrm{m}$, Premium Bifurcated Fiber, UV-VIS, $2 \mathrm{~m}$, ATO, Largo, FL, USA) adjusted at $45^{\circ}$ to the sample surface and connected to a dual-channel Ocean-Optics spectrometer (LIBS 2500plus, Ocean Optics Inc., Dunedin, FL, USA). The laser beam was directly focused on the surface of the samples through a $150 \mathrm{~mm}$ focal length lens. In order to avoid detector saturation, pulse energy and irradiance were set at $30 \mathrm{~mJ}$ and $73.5 \mathrm{MW} / \mathrm{cm}^{2}$, respectively.

Semi-quantitative compositional analysis and morphology were characterized by means of field emission scanning electron microscopy (FESEM) using a Carl Zeiss MERLIN microscope with an incorporated energy dispersive X-ray detector (EDX) (Carl Zeiss microscopy GmbH, Munich, Germany). X-ray diffraction (XRD) analyses were carried out to determine the amorphous character of glass samples by means of a Bruker D8 Advance diffractometer (Bruker, Billerica, MA, USA). Raman dispersion measurements were performed using a confocal Raman spectrometer (Witec Alpha $300 \mathrm{M}+$ ) (Witec, Ulm, Germany) equipped with a thermoelectric-cooled CCD detector. As the excitation source, a $488 \mathrm{~nm}$ laser was used and the scattered light was collected through a $50 \times$ microscope objective 
lens. The output power of the laser was kept below $1 \mathrm{~mW}$ in order to avoid significant local heating of the sample.

\section{Results and Discussion}

Figure 1 shows LIBS spectra recorded in the spectral range of $200-850 \mathrm{~nm}$ for both the W-TCP eutectic glass and layer developed on the sample surface after being soaked into SBF for one month. The LIBS spectrum of HA is also presented for comparison purposes [37]. The spectra show strong characteristic emission lines that can be assigned according to the National Institute of Standards and Technology (NIST). The main atomic emission lines corresponding to $\mathrm{Si}$ (I), $\mathrm{Ca}$ (I), $\mathrm{Ca}$ (II), $\mathrm{Mg}$ (II), $\mathrm{Na}$ (I), and $\mathrm{O}$ (I) are pointed out in the figure and the assigned wavelengths are listed in Table 1 . When the dense W-TCP eutectic glass is immersed in SBF, the reaction of the material with the SBF gives rise to a porous layer of HA, which finally covers the surface of the sample. It is well known that for a glass to be bioactive and, hence, to bond to bone, a calcium phosphate layer must form at its surface. The mechanisms of this reaction were proposed by Hench et al. [1,2], and can be summarized in the following five stages: (i) rapid exchange of alkali or alkali-earth ions with $\mathrm{H}^{+}$or $\mathrm{H}_{3} \mathrm{O}^{+}$from solution; (ii) loss of soluble silica in the form of $\mathrm{Si}(\mathrm{OH})_{4}$ to the solution; (iii) condensation and repolymerization of $\mathrm{SiO}_{2}$-rich layer on the surface depleted in alkalis and alkaline-earth cations; (iv) migration of $\mathrm{Ca}^{2+}$ and $\mathrm{PO}_{4}{ }^{3-}$ groups to the surface through the $\mathrm{SiO}_{2}$-rich layer forming a $\mathrm{CaO}-\mathrm{P}_{2} \mathrm{O}_{5}$-rich film on top of the $\mathrm{SiO}_{2}$-rich layer, followed by the growth of the amorphous $\mathrm{CaO}-\mathrm{P}_{2} \mathrm{O}_{5}$-rich film by incorporation of soluble calcium and phosphorous from solution; and (v) crystallization of the amorphous $\mathrm{CaO}-\mathrm{P}_{2} \mathrm{O}_{5}$ film by incorporation of $\mathrm{OH}^{-}$anions from solution to form a hydroxyapatite layer.

Figure 2 shows LIBS spectral emission lines of Si (I) at 243.5 (a), 250.69, 251.61, 252.41, 252.85 (b), 263.1 (c), and 288.16 (d). It can be observed that none of these spectral emission signals appeared in the layer produced after immersion in SBF, thus confirming the absence of silicon in the layer developed on the surface of the sample.

(a)

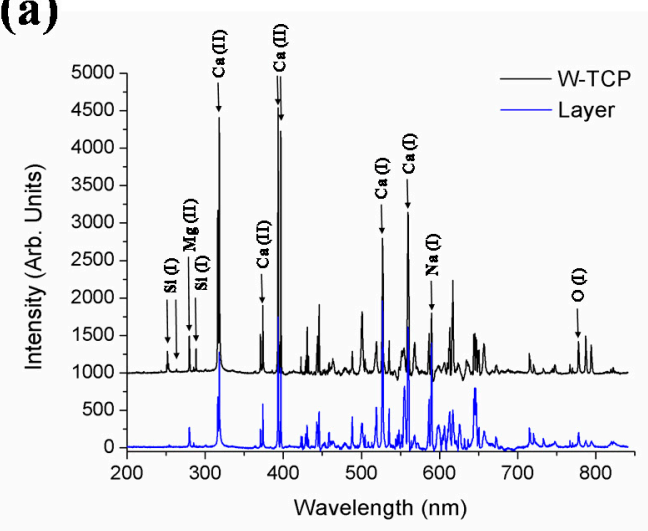

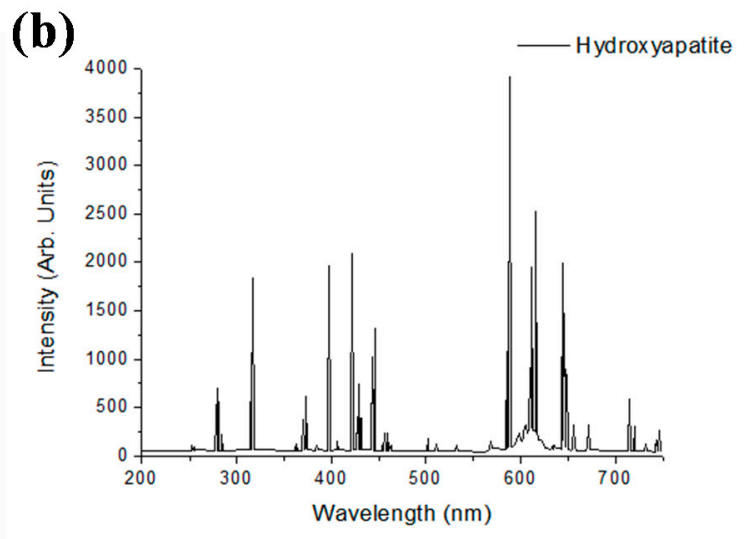

Figure 1. Comparative LIBS spectra between the W-TCP eutectic glass and the layer produced on the surface of the sample (a). The spectra shown are the average of 10 shots with an integration time of $3 \mathrm{~ms}$. The HA LIBS spectrum is also presented for comparison purposes (b).

Table 1. List of the main spectral lines observed in the samples.

\begin{tabular}{ccc}
\hline Element & Sample & Wavelength $(\mathbf{n m})$ \\
\hline $\mathrm{Si}$ (I) & W-TCP & 243.5, 250.69, 251.61, 252.41, 252.85, 263.1, 288.16 \\
$\mathrm{Ca}$ (I) & W-TCP, HA & $527.03,559.45$ \\
$\mathrm{Ca}$ (II) & W-TCP, HA & $317.93,373.69,393.37,396.85$ \\
$\mathrm{Mg}$ (II) & W-TCP, HA & 279.55 \\
$\mathrm{Na}$ (I) & W-TCP, HA & 589 \\
$\mathrm{O}$ (I) & W-TCP, HA & 777.5 \\
\hline
\end{tabular}


(a)

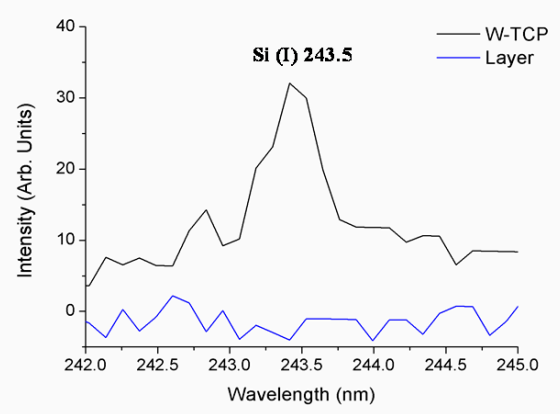

(c)

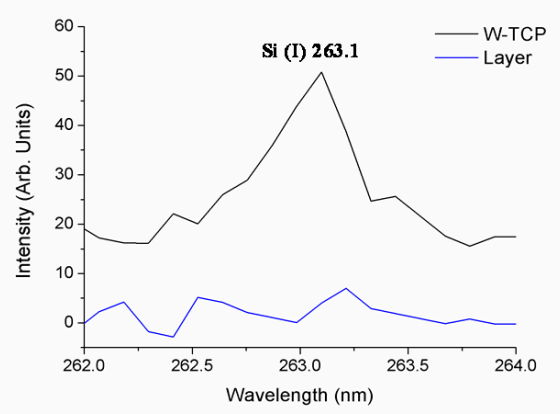

(b)

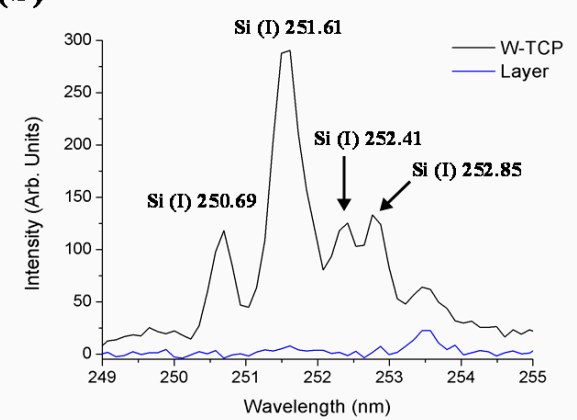

(d)

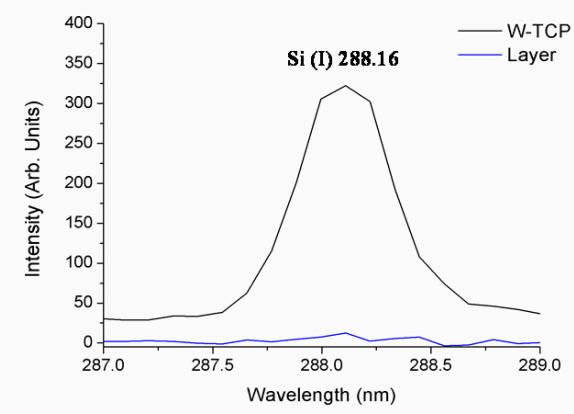

Figure 2. LIBS spectral signals of Si (I) in both the W-TCP eutectic glass and the HA layer at $243.5 \mathrm{~nm}$ (a), 250.69, 251.61, 252.41, $252.85 \mathrm{~nm}(\mathbf{b}), 263.1$ (c) and 288.16 (d).

Next, both the chemical composition and structure of the layer produced on the surface of the sample after a one-month immersion in SBF was investigated by micro-Raman spectroscopy for two wavenumber regions; $50-1200 \mathrm{~cm}^{-1}$ and $3500-3700 \mathrm{~cm}^{-1}$ (Figure 3). The Raman spectrum of standard TCP is also presented for comparison purposes. The Raman spectra collected were made up of sharp peaks and broad bands which can be assigned to the HA Raman spectra previously reported in the scientific literature [9,26]; a narrow intense peak located at $962 \mathrm{~cm}^{-1}$, corresponding to symmetric stretching of $\mathrm{PO}_{4}{ }^{3-}$ modes, and broad bands at 400-500, 570-625 and 1020-1095 $\mathrm{cm}^{-1}$ are attributed, respectively, to $v_{2}{ }^{-}, v_{4}{ }^{-}$, and $v_{3}{ }^{-}$type internal $\mathrm{PO}_{4}{ }^{3-}$ modes, and a strong sharp peak located at $3576 \mathrm{~cm}^{-1}$ is assigned to the $\mathrm{O}-\mathrm{H}$ stretching mode. It is worth highlighting that HA Raman spectra show significant variations when compared to TCP spectra, the most relevant of which is that the $\mathrm{O}-\mathrm{H}$ stretching mode did not appear. Therefore, micro-Raman analyses carried out on the layer developed on the sample surface confirmed the generation of a HA layer.

(a)

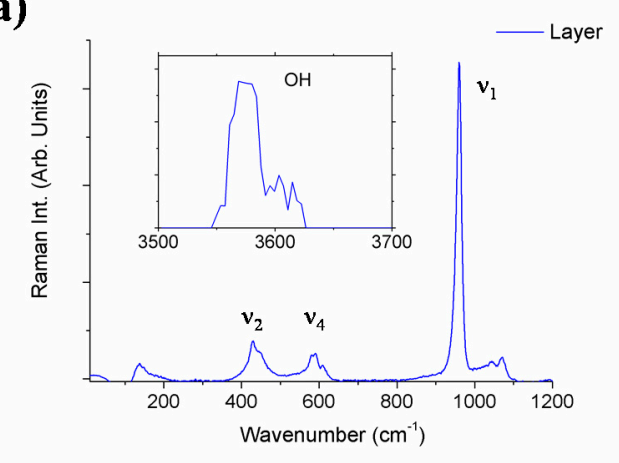

(b)

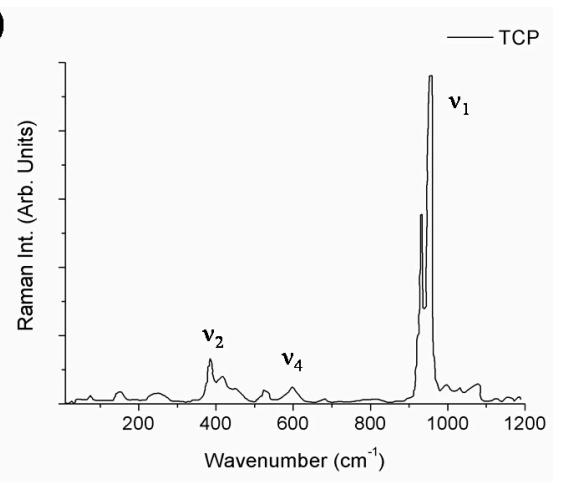

Figure 3. Micro-Raman spectra collected on the surface of the sample after a one-month immersion in SBF (a). The standard TCP Raman spectrum is also presented for comparison purposes (b). 
Finally, microstructural and semi-quantitative chemical composition analyses were carried out by SEM-EDX aiming at analysing the morphology of the sample, determining the elements both the glass and the layer were comprised of, and the $\mathrm{Ca} / \mathrm{P}$ ratio of the layer. Figure 4 shows a general view micrograph of the sample soaked in SBF (a) and a detail of the layer (b). SEM observation showed that a new layer was formed on the surface of the samples, which consisted of HA nanocrystals, fibrillar in shape, and randomly oriented, thus providing porosity to the new surface. The cracks observed revealed that the coating formed had different properties than the parent glass, as cracks were not present on starting samples. The EDX spectrum shown in Table 2 indicates that the composition of the glass is close to the theoretical value. In addition, these analyses revealed the formation on the surface of the glass of a layer rich in $\mathrm{Ca}$ and $\mathrm{P}$, with a $\mathrm{Ca} / \mathrm{P}$ ratio of about 1.3 . It is worth mentioning that these analyses corroborated that Si was not present in the layer. Thus, during immersion, the bioactive glass surface dissolved and a new surface formed by precipitation and transformation reactions leading to a crystallized, Ca-deficient apatite, similar to bone in its composition.

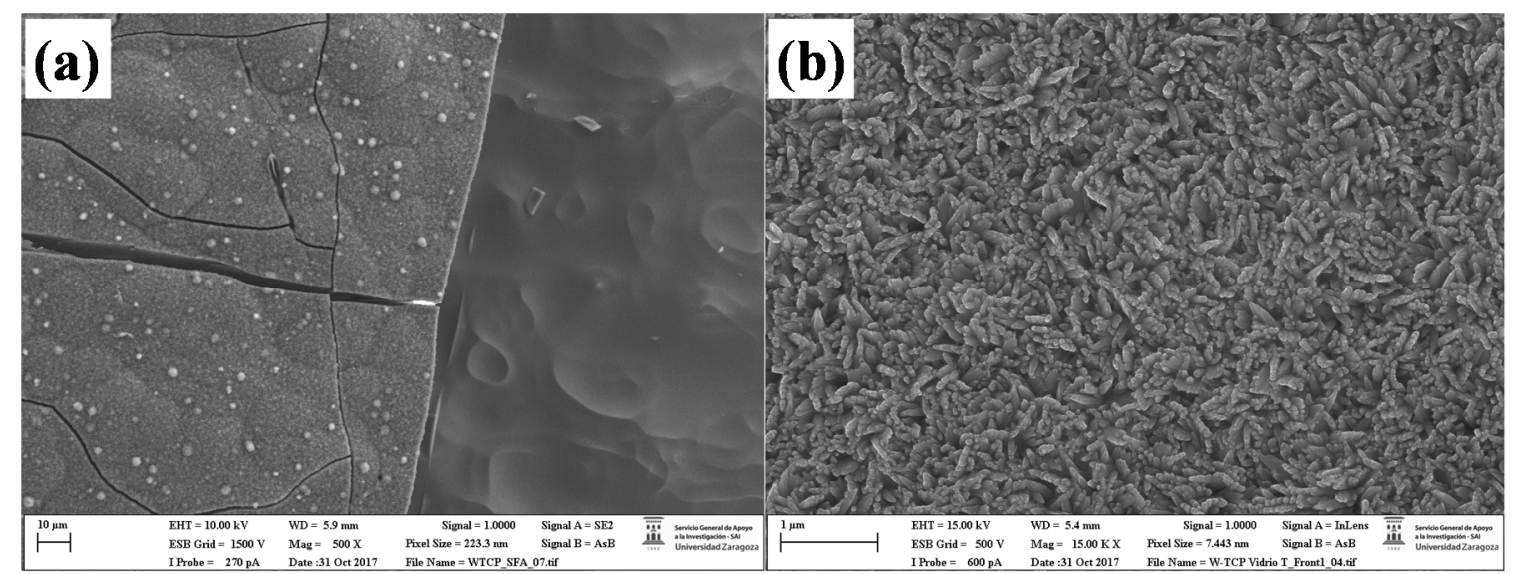

Figure 4. SEM micrographs of the W-TCP eutectic sample after a one-month immersion in SBF. General view (a), and a detail of the layer developed on the surface $(\mathbf{b})$.

Table 2. EDX compositional analysis in at \% of both the W-TCP glass and surface layer.

\begin{tabular}{cccc}
\hline Sample & Si & $\mathbf{P}$ & Ca \\
\hline Glass & 12.73 & 6.27 & 18.86 \\
Layer & - & 16.56 & 21.70 \\
\hline
\end{tabular}

\section{Conclusions}

W-TCP eutectic glasses were soaked in simulated body fluid for a one-month period of time in which a hydroxyapatite porous layer was developed on the surface. Laser-induced breakdown spectroscopy (LIBS) spectra acquired on the sample surface showed that Si (I) emission lines were not present in the layer developed after the immersion period. Micro-Raman spectroscopy analyses carried out on the surface confirmed the crystalline nature of this layer, the Raman spectra of which corresponded to hydroxyapatite. Finally, SEM-EDX characterization indicated that the layer composition was rich in $\mathrm{Ca}$ and $\mathrm{P}$ with a $\mathrm{Ca} / \mathrm{P}$ ratio around 1.3 and at the same time corroborating the $\mathrm{Si}$ absence on the layer.

Acknowledgments: Daniel Sola thanks the Ministry of Economy and Competitiveness of the State General Administration under the project MINECO FIS2016-76163-R and the PIT2 program of the University of Murcia's own research plan for the financial support of his contract. Additionally, this work was partially supported by the Department of Research and Innovation, the University of the Aragon Regional Government, the European Social Fund (group E75), the University of Zaragoza (proposal UZ2015-CIE-01), and the General Services Research Support-SAI of the University of Zaragoza. 
Author Contributions: Daniel Sola led the investigation, manufactured the glasses, analysed the micro-Raman spectra, and edited the manuscript. Daniel Paulés and Jesús Anzano performed the LIBS studies and analysed he LIBS spectra. Lorena Grima performed the in vitro experiments and characterized the samples by SEM-EDX and micro-Raman spectroscopy.

Conflicts of Interest: The authors declare no conflict of interest.

\section{References}

1. Hench, L.L.; Splinter, R.J.; Greenle, T.K.; Allen, W.C. Bonding mechanisms at the interface of ceramic prosthetic materials. J. Biomed. Mater. Res. 1971, 2, 117-141. [CrossRef]

2. Hench, L.L.; Wilson, J. An Introduction to Bioceramics, 2nd ed.; Imperial College Press: London, UK, 2013.

3. Best, S.M.; Porter, A.E.; Thian, E.S.; Huan, J. Bioceramics: Past, present and for the future. J. Eur. Ceram. Soc. 2008, 28, 1319-1327. [CrossRef]

4. Lu, J.X.; Flautre, B.; Anselme, K.; Hardouin, P.; Gallur, A.; Descamps, M.; Thierry, B. Role of interconnections in porous bioceramics on bone recolonization in vitro and in vivo. J. Mater. Sci. Mater. Med. 1999, 10, 111-120. [CrossRef] [PubMed]

5. De Groot, K.; Le Geros, R. Significance of Porosity and Physical Chemistry of Calcium Phosphate Ceramics; Ducheyne, P., Ed.; Annal New York Academy Sciences: New York, NY, USA, 1988.

6. Von Doernberg, M.C.; von Rechenberg, B.; Bohner, M.; Grunenfelder, S.; van Lenthe, G.H.; Muller, R.; Gasser, B.; Mathys, R.; Baroud, G.; Auer, J. In vivo behaviour of calcium phosphate scaffolds with four different pore sizes. Biomaterials 2006, 27, 5186-5198. [CrossRef] [PubMed]

7. Bungo, O.; Mitsuru, T.; Shunsuke, F.; Masashi, N.; Tadashi, K.; Takashi, N. Pore throat size and connectivity determine bone and tissue ingrowth into porous implants: Tree-dimensional micro-CT based structural analyses of porous bioactive titanium implants. Biomaterial 2006, 27, 5892-5900.

8. De Aza, P.N.; Guitian, F.; de Aza, S. Phase diagram of wollastonite-tricalcium phosphate. J. Am. Ceram. Soc. 1995, 78, 1653-1656. [CrossRef]

9. De Aza, P.N.; Guitian, F.; de Aza, S. Bioeutectic: A new ceramic material for human bone replacement. Biomaterials 1997, 18, 1285-1291. [CrossRef]

10. Magallanes-Perdomo, M.; de Aza, A.H.; Sobrados, I.; Sanz, J.; Pena, P. Structure and properties of bioactive eutectic glasses based on the $\mathrm{Ca}_{3}\left(\mathrm{PO}_{4}\right)_{2}-\mathrm{CaSiO}_{3}-\mathrm{CaMg}\left(\mathrm{SiO}_{3}\right)_{2}$ system. Acta Biomater. 2012, 8, 820-829. [CrossRef] [PubMed]

11. Llorca, J.; Orera, V.M. Directionally-solidified eutectic ceramic oxides. Prog. Mater. Sci. 2006, 51, 711-809. [CrossRef]

12. Sola, D.; Ester, F.J.; Oliete, P.B.; Peña, J.I. Study of the stability of the molten zone and the stresses induced during the growth of $\mathrm{Al}_{2} \mathrm{O}_{3}-\mathrm{Y}_{3} \mathrm{Al}_{5} \mathrm{O}_{12}$ eutectic composite by the laser floating zone technique. J. Eur. Ceram. Soc. 2011, 31, 1211-1218. [CrossRef]

13. Ester, F.J.; Sola, D.; Peña, J.I. Thermal stresses in the $\mathrm{Al}_{2} \mathrm{O}_{3}-\mathrm{ZrO}_{2}\left(\mathrm{Y}_{2} \mathrm{O}_{3}\right)$ eutectic composite during the growth by the laser floating zone technique. Bol. Soc. Esp. Ceram. 2008, 47, 352-357. [CrossRef]

14. Sola, D.; Peña, J.I. Laser machining of $\mathrm{Al}_{2} \mathrm{O}_{3}-\mathrm{ZrO}_{2}\left(3 \% \mathrm{Y}_{2} \mathrm{O}_{3}\right)$ eutectic composite. J. Eur. Ceram. Soc. 2012, 32 , 807-814. [CrossRef]

15. Orera, V.M.; Peña, J.I.; Merino, R.I.; Lazaro, J.A.; Valles, J.A.; Rebolledo, M.A. Prospects of new planar optical waveguides based on the eutectic microcomposites of insulating crystals: $\mathrm{ZrO}_{2}$ (c)-CaZrO 3 erbium doped system. Appl. Phys. Lett. 1997, 71, 2746-2748. [CrossRef]

16. Sola, D.; Oliete, P.B.; Peña, J.I. Directionally solidified fabrication in planar geometry of $\mathrm{Al}_{2} \mathrm{O}_{3}-\mathrm{Er}_{3} \mathrm{Al}_{5} \mathrm{O}_{12}$ eutectic composite for thermophotovoltaic devices. Opt. Express 2016, 24, A823-A831. [CrossRef] [PubMed]

17. Pardo, J.A.; Peña, J.I.; Merino, R.I.; Cases, R.; Larrea, A.; Orera, V.M. Spectroscopic properties of $\mathrm{Er}^{3+}$ and $\mathrm{Nd}^{3+}$ doped glasses with $0.8 \mathrm{CaSiO}_{3}-0.2 \mathrm{Ca}_{3}\left(\mathrm{PO}_{4}\right)_{2}$ eutectic composition. J. Non-Cryst. Solids 2002, 298, $23-31$. [CrossRef]

18. Sola, D.; Balda, R.; Peña, J.I.; Fernandez, J. Site-selective laser spectroscopy of $\mathrm{Nd}^{3+}$ ions in $0.8 \mathrm{CaSiO}_{3}-0.2 \mathrm{Ca}_{3}\left(\mathrm{PO}_{4}\right)_{2}$ biocompatible eutectic glass-ceramics. Opt. Express 2012, 20, 10701-10711. [CrossRef] [PubMed]

19. Sola, D.; Balda, R.; Al-Saleh, M.; Peña, J.I.; Fernandez, J. Time-resolved fluorescence line-narrowing of Eu ${ }^{3+}$ in biocompatible eutectic glass-ceramics. Opt. Express 2013, 21, 6561-6571. [CrossRef] [PubMed] 
20. De Mendivil, J.M.; Sola, D.; de Aldana, J.R.V.; Lifante, G.; De Aza, A.H.; Pena, P.; Peña, J.I. Ultrafast direct laser writing of cladding waveguides in the $0.8 \mathrm{CaSiO}_{3}-0.2 \mathrm{Ca}_{3}\left(\mathrm{PO}_{4}\right)_{2}$ eutectic glass doped with $\mathrm{Nd}^{3+}$ ions. J. Appl. Phys. 2015, 117, 043104. [CrossRef]

21. Sola, D.; De Mendibil, J.M.; De Aldana, J.R.V.; Lifante, G.; Balda, R.; De Aza, A.H.; Pena, P.; Fernandez, J. Stress-induced buried waveguides in the $0.8 \mathrm{CaSiO}_{3}-0.2 \mathrm{Ca}_{3}\left(\mathrm{PO}_{4}\right)_{2}$ eutectic glass doped with $\mathrm{Nd}^{3+}$ ions. Appl. Surf. Sci. 2013, 278, 289-294. [CrossRef]

22. Carrodeguas, R.G.; de Aza, S. $\alpha$-Tricalcium phosphate: Synthesis, properties and biomedical applications. Acta Biomater. 2011, 7, 3536-3546. [CrossRef] [PubMed]

23. De Aza, P.N.; Luklinska, Z.B.; Anseau, M.R.; Hector, M.; Guitian, F.; De Aza, S. Reactivity of a wollastonite-tricalcium phosphate Bioeutectic ${ }^{\circledR}$ ceramic in human parotid saliva. Biomaterials 2000, 21, 1735-1741. [CrossRef]

24. De Aza, P.N.; Guitian, F.; de Aza, S. A new bioactive material which transforms in situ into hydroxyapatite. Acta Mater. 1998, 46, 2541-2549. [CrossRef]

25. Magallanes-Perdomo, M.; Pena, P.; de Aza, P.N.; Carrodeguas, R.G.; Rodríguez, M.A.; Turrillas, X.; de Aza, S.; de Aza, A.H. Devitrification studies of wollastonite-tricalcium phosphate eutectic glass. Acta Biomater. 2009, 5, 3057-3066. [CrossRef] [PubMed]

26. De Aza, P.N.; Peña, J.I.; Luklinska, Z.B.; Meseguer-Olmo, L. Bioeutectic ${ }^{\circledR}$ ceramics for biomedical application obtained by Laser Floating Zone method. In vivo Evaluation. Materials 2014, 7, 2395-2410. [CrossRef] [PubMed]

27. Magallanes-Perdomo, M.; De Aza, A.H.; Sobrados, I.; Sanz, J.; Luklinska, Z.B.; Pena, P. Structural changes during crystallization of apatite and wollastonite in the eutectic glass of $\mathrm{Ca}_{3}\left(\mathrm{PO}_{4}\right)_{2}-\mathrm{CaSiO}_{3}$ system. J. Am. Ceram. Soc. 2017, 100, 4288-4304. [CrossRef]

28. Paules, D.; Hamida, S.; Lasheras, R.J.; Escudero, M.; Benouali, D.; Cáceres, J.O.; Anzano, J. Characterization of natural and treated diatomite by Laser-Induced Breakdown Spectroscopy (LIBS). Microchem. J. 2018, 137, 1-7. [CrossRef]

29. Cremers, D.A.; Radziemski, L.J. Handbook of Laser-Induced Breakdown Spectroscopy, 2nd ed.; Wiley-Blackwell: Oxford, UK, 2013.

30. Hahn, D.W.; Omenetto, N. Laser-Induced Breakdown Spectroscopy (LIBS), Part I: Review of Basic Diagnostics and Plasma-Particle Interactions: Still-Challenging Issues within the Analytical Plasma Community. Appl. Spectrosc. 2010, 64, 335-366. [CrossRef] [PubMed]

31. Hahn, D.W.; Omenetto, N. Laser-Induced Breakdown Spectroscopy (LIBS), Part II: Review of Instrumental and Methodological Approaches to Material Analysis and Applications to Different Fields. Appl. Spectrosc. 2012, 66, 347-419. [CrossRef] [PubMed]

32. Miziolek, A.W.; Palleschi, V.; Schechter, I. Laser-Induced Breakdown Spectroscopy (LIBS). Fundamentals and Applications; Cambridge University Press: Cambridge, UK, 2006.

33. Parigger, C.G. Atomic and molecular emissions in laser-induced breakdown spectroscopy. Spectrochim. Acta Part B At. Spectrosc. 2013, 79-80, 4-16. [CrossRef]

34. Sola, D.; Conejos, D.; de Mendivil, J.M.; Ortega-San-Martin, L.; Lifante, G.; Peña, J.I. Directional solidification, thermo-mechanical and optical properties of $\left(\mathrm{Mg}_{\mathrm{x}} \mathrm{Ca}_{1-\mathrm{x}}\right)_{3} \mathrm{Al}_{2} \mathrm{Si}_{3} \mathrm{O}_{12}$ glasses doped with $\mathrm{Nd}^{3+}$ ions. Opt. Express 2015, 23, 26356-26368. [CrossRef] [PubMed]

35. Arias-Egido, E.; Sola, D.; Pardo, J.A.; Martínez, J.I.; Cases, R.; Peña, J.I. On the control of optical transmission of aluminosilicate glasses manufactured by the laser floating zone technique. Opt. Mater. Express 2016, 6, 2413-2421. [CrossRef]

36. Oyane, A.; Kim, H.; Furuya, T.; Kokubo, T.; Miyazaki, T.; Nakamura, T. Preparation and assessment of revised simulated body fluid. J. Biomed. Mater. Res. A 2003, 65, 188-195. [CrossRef] [PubMed]

37. Tariq, U.; Haider, Z.; Hussain, R.; Tufail, K.; Ali, J. LIBS Analysis of Hydroxyapatite Extracted from Bovine Bone for Ca/P Ratio Measurements. In Proceedings of the 9th International Conference on Plasma Science and Applications, Langkawi, Malaysia, 28-30 November 2017; Volume 1824.

(C) 2017 by the authors. Licensee MDPI, Basel, Switzerland. This article is an open access article distributed under the terms and conditions of the Creative Commons Attribution (CC BY) license (http:// creativecommons.org/licenses/by/4.0/). 